\title{
ArcheoSciences
}

Revue d'archéométrie

\section{Significance of the correlation between the electrical conductivity dataset and lithology in Pleni-Lateglacial and Holocene alluvial archives. A case study: the Choisille catchment (SW Paris Basin, France)}

Eymeric Morin, Florent Hinschberger, Jean-Jacques Macaire, Isabelle GayOvéjéro and Caroline Chartin

\section{(2) OpenEdition}

Electronic version

URL: https://journals.openedition.org/archeosciences/1566

DOI: 10.4000/archeosciences. 1566

ISBN: 978-2-7535-1599-4

ISSN: 2104-3728

Publisher

Presses universitaires de Rennes

Printed version

Date of publication: 30 October 2009

Number of pages: 191-194

ISBN: 978-2-7535-0943-6

ISSN: 1960-1360

\section{Electronic reference}

Eymeric Morin, Florent Hinschberger, Jean-Jacques Macaire, Isabelle Gay-Ovéjéro and Caroline Chartin, "Significance of the correlation between the electrical conductivity dataset and lithology in Pleni-Lateglacial and Holocene alluvial archives.

A case study: the Choisille catchment (SW Paris Basin, France)", ArcheoSciences [Online], 33 (suppl.) | 2009, Online since 30 October 2011, connection on 01 February 2022. URL: http:// journals.openedition.org/archeosciences/1566 ; DOI: https://doi.org/10.4000/archeosciences. 1566 


\title{
Significance of the correlation between the electrical conductivity dataset and lithology in Pleni-Lateglacial and Holocene alluvial archives. A case study: the Choisille catchment (SW Paris Basin, France)
}

\author{
Eymeric Morin*, Florent Hinschberger*, Jean-Jacques Macaire*, \\ Isabelle GaY-OvéJÉro* and Caroline Chartin*
}

Keywords: Alluvial sediment, Electromagnetic prospecting, Conductivity, Palaeoenvironment, Weathering.

\section{INTRODUCTION}

Alluvial floodplains constitute rapidly evolving sedimentary environments, registering both climate changes and human impact. In the Paris Basin, the floodplain filling is generally composed of two major units (Pastre et al., 2003; Macaire et al., 2006): coarse deposits (sands and gravels) from the Pleniglacial or Late Glacial in the lower part and fine deposits (clayey-silty to carbonated or peaty sediments) from the Late Glacial and Holocene in the upper part. Because of its high palaeoenvironmental significance, it is important to know precisely the border between these two units, a surface that is often irregular and corresponds to a lack of sedimentation or even erosion. This surface can be defined by boreholes, which give only limited information however. In most cases, electrical and electromagnetical surveys provide information on valley floor sedimentary filling features and thickness over large areas (Gourry et al., 2003). The measured parameter is the electrical conductivity (in milli-Siemens per meter), closely depending on the litho- logy, granularity and water content of superficial deposits, the latter related to sediment porosity (Tabbagh \& Cosenza, 2006). In the case of a resistive substratum, low conductivities are usually associated with coarse overlying alluvial deposits (sands and/or gravels) or thin sedimentary filling, whereas high conductivities may indicate a thick layer of fine deposits (clays and/or silts).

For this purpose, boreholes and a geophysics (EM31 electromagnetical prospecting) dataset on Pleniglacial, Late Glacial and Holocene alluvial sediments were combined. The aim of this work is to characterize deposit geometry and to assess palaeoenvironmental significance of the correlation between electrical conductivity and lithology in recent fluvial archives.

\section{STUDY AREA}

The Choisille catchment ( $288 \mathrm{~km}^{2}$; elevation: $\left.45-200 \mathrm{~m}\right)$ is located north of Tours in the southwest of the Paris Basin

* Institution: Université François-Rabelais de Tours/CNRS-INSU/Université d'Orléans (UMR6113 ISTO). (eymeric.morin@etu.univ-tours.fr) 

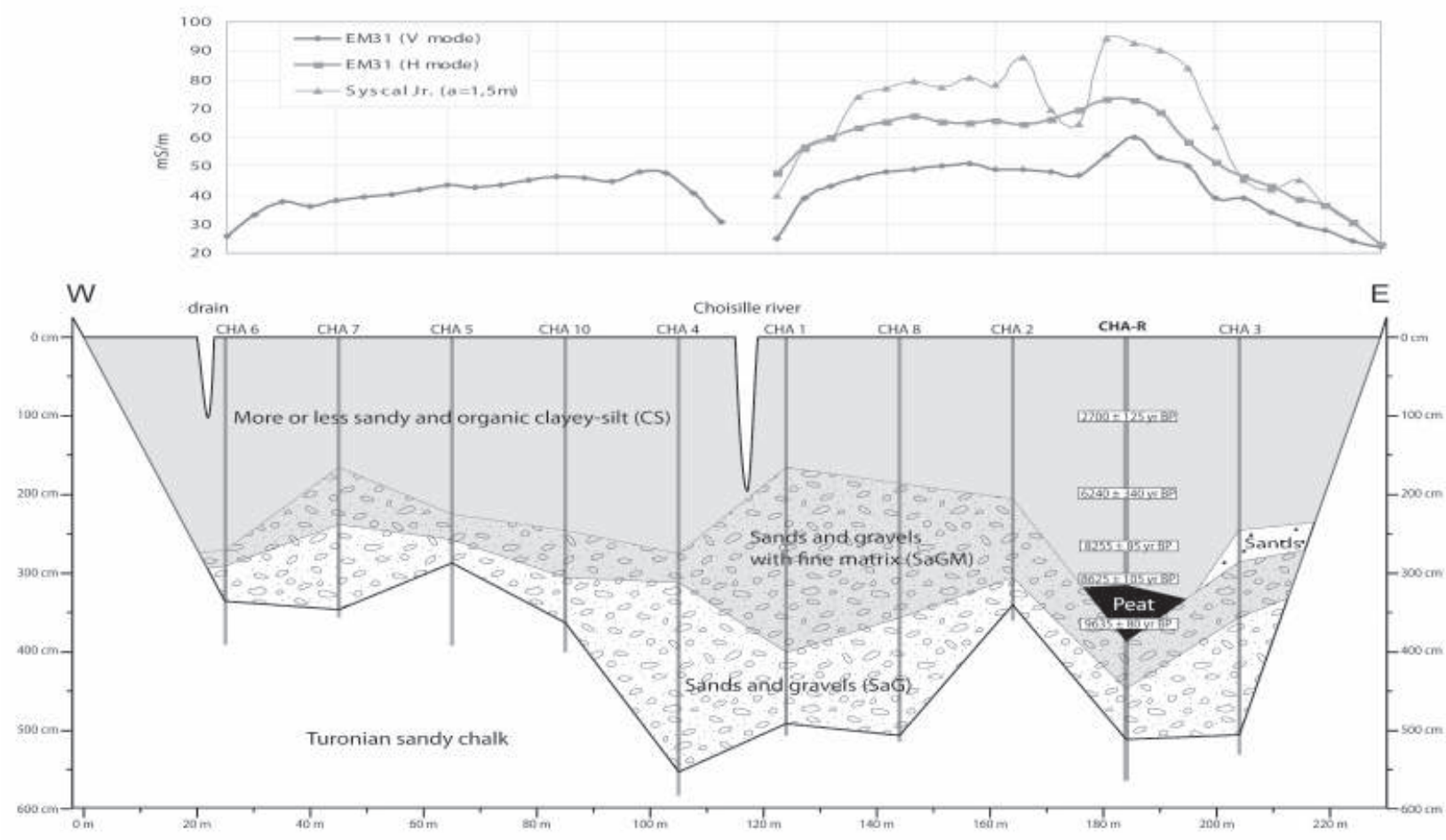

Figure 1

(France). 26 boreholes along three transects were performed with a percussion sampler through valley-floor fluvial sediments in the downstream stretch. These boreholes have shown that the Pleniglacial, Late Glacial and Holocene deposits overlying the Turonian sandy chalk have a maximum thickness of $5.8 \mathrm{~m}$. General sediment features are, from bottom to top (Fig. 1): sands and gravels without matrix $(\mathrm{SaG})$ with a maximum thickness of $2.4 \mathrm{~m}$; sands and gravels with silty-clayey matrix $(\mathrm{SaGM})$ with a maximum thickness of $2.4 \mathrm{~m}$ and interpreted as a weathering feature of $\mathrm{SaG}$. SaG $+\mathrm{SaGM}$ thickness can reach $3.2 \mathrm{~m}$ and its very irregular surface presents depressions (palaeochannels) filled with peat, dating from the Alleröd (overlying $\mathrm{SaG}$ ) or Preboreal (overlying $\mathrm{SaGM}$ ). The upper part of the alluvial filling, between 0 and about $2.5 \mathrm{~m}$ depth, is homogeneous and composed of more or less sandy and organic clayey-silts (CS), deposited since the Boreal period.

\section{Methods}

Electromagnetic prospection was performed using an EM31 conductivity meter (Geonics Ltd. ${ }^{\circ}$ ), which is described in detail by McNeill (1980). The instrument measu- res the apparent electrical conductivity of the ground with an investigation depth of approximately $6 \mathrm{~m}$, making it well appropriate for the Choisille sedimentary filling study. We performed about $24 \mathrm{~km}$ of electromagnetic profiles within the Choisille alluvial plain, representing 3500 measurement points (Fig. 2). An electrical survey was performed at 21 points in the Choisille alluvial plain, using a Syscal Jr. resistivity meter (Iris Instrument ${ }^{\oplus}$ ) to better define the vertical distribution of sediments and to help interpret electromagnetic mapping.

\section{RESULTS AND DISCUSSION}

The electromagnetic profiling survey has enabled the construction of a large-scale map of shallow sub-surface apparent conductivity, covering about 37 ha (Fig. 2). The measured conductivity ranges from $10 \mathrm{mS} / \mathrm{m}$ at the edges of the valley to $70 \mathrm{mS} / \mathrm{m}$ in the more central parts. The EM31 survey highlights linear conductive $(>50 \mathrm{mS} / \mathrm{m})$ structures running parallel to the axis of the valley, clearly interpreted as palaeochannels filled with fine deposits. The alluvial floodplain is generally characterised by abrupt boundaries, where the measured apparent conductivity decreases from about 


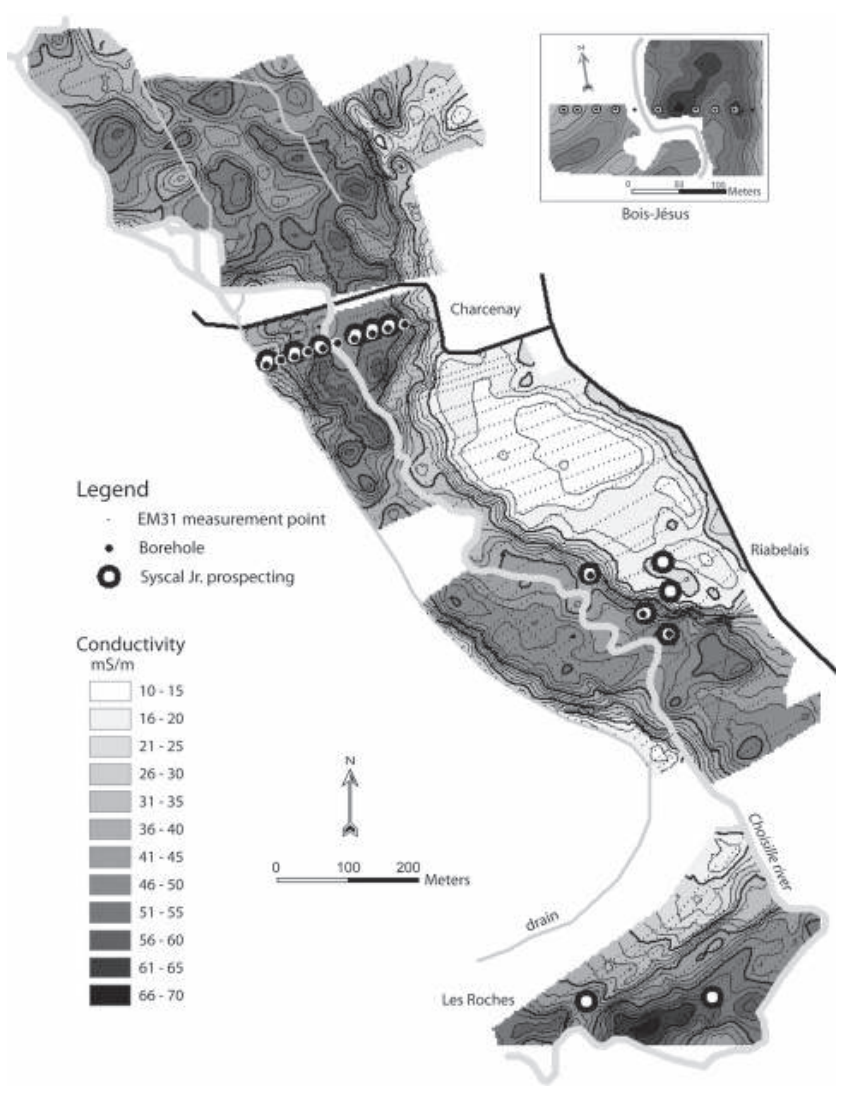

Figure 2

$40 \mathrm{mS} / \mathrm{m}$ to less than $20 \mathrm{mS} / \mathrm{m}$ over a distance of $15-20 \mathrm{~m}$, whereas no major topographic changes are observed. These resistive zones correspond to a low depth substrate (thin or no alluvial filling).

Results show that the increase in sediment thickness is related to an increase of conductivity measured with EM31. The best correlation $\left(\mathrm{R}^{2}=0.93\right)$ is obtained considering the thickness of all sediments except $\mathrm{SaG}$ (Fig. 3). This group of deposits is made of sands and gravels with a matrix of peat and more or less sandy/organic clayey-silts (SaGM/PCS). It is characterised by high conductivity values resulting from the fine granularity of sediment bulk or matrix (for coarse sediments). This good correlation between conductivity measured with EM31 and the thickness of SaGM/PCS deposits observed in boreholes enables a mapping of the predicted thickness to be established for the entire prospected area. These maps highlight the border between $\mathrm{SaG}$ and $\mathrm{SaGM}$, which is the base of the weathered layer ("weathering front") in SaG. This border does not seem to be the result of initial deposition due to distinct lithology, but of post- depositional evolution of the coarse unit, which indicates a lack of sedimentation and erosion and weathering, probably spatially diachronic, of SaG. Dating obtained for the peat

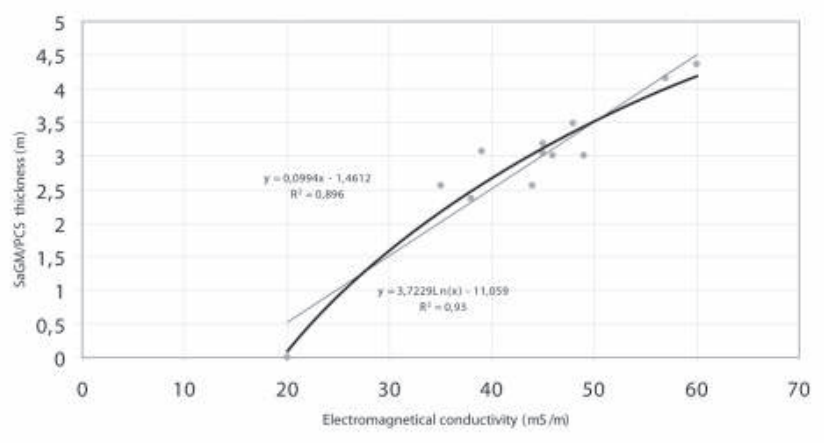

Figure 3

help to restrict this period to the Late Glacial and the Early Holocene. The end of this period can be said to correspond approximately to an increase in clayey-silty sedimentation in relation to human activities in the catchment area.

\section{Conclusion}

The geophysical electromagnetical method enables the border between sands and gravels without matrix and the overlying sands and gravels with matrix to be established. It is not a border due to depositional processes, but corresponds to the weathering front of the $\mathrm{SaG}$ deposit, developed during the Late Glacial, a period characterized by lack of sedimentation.

\section{References}

Gourry, J.C., Vermeersch, F., Garcin, M., Giot, D., 2003. Contribution of geophysics to the study of alluvial deposits: a case study in the Val d'Avaray area of the River Loire, France. Journal of Applied Geophysics, 54: 35-49.

Macaire, J.J., Bernard, J., Di Giovanni, C., Hinschberger, F., Limondin-Lozouet, N., Visset, L., 2006. Quantification and regulation of organic and mineral sedimentation in a late- Holocene floodplain as a result of climatic and human impacts (Taligny marsh, Parisian basin, France). The Holocene, 16 (5): 647-660.

Mc NeILl, J.D., 1980. Electromagnetic terrain conductivity measurement at low induction numbers. Geonics limited, technical note TN-6.

Pastre, J.F., Limondin-Louzouet, N., Leroyer, C., Ponel, P., Fontugue, M., 2003. River system evolution and envi- 
ronmental changes during the Lateglacial in the Paris Basin (France). Quaternary Science Reviews, 22: 2177-2188.

Tabbagh, A., Cosenza, P., 2006. Effect of microstructure on the electrical conductivity of clay-rich systems. Physics and Chemistry of the Earth, 32: 154-160. 